\title{
Knowledge, attitudes, and practices related to COVID-19 Pandemic among healthcare workers in the United Arab Emirates: A cross-sectional study
}

\author{
Amina M. Al Marzouqi \\ University of Sharjah \\ Michael E. Otim ( $\square$ motim@sharjah.ac.ae) \\ University of Sharjah \\ Leena S. Kehail \\ University of Sharjah \\ Ramsha A. Kamal \\ University of Sharjah
}

\section{Research Article}

Keywords: COVID-19 Pandemic Knowledge, COVID-19 Pandemic Attitudes, COVID-19 Pandemic Practice, COVID-19 Pandemic, Healthcare workers, United Arab Emirates

Posted Date: December 9th, 2021

DOI: https://doi.org/10.21203/rs.3.rs-770359/v2

License: (9) This work is licensed under a Creative Commons Attribution 4.0 International License.

Read Full License 


\section{Abstract}

Background: Coronavirus disease (COVID-19 Pandemic) is an infectious disease caused by the SARSCoV-2 virus. It is a global health issue that continues to have an impact on many aspects of everyday life. A new variant, Omicron variant, has just been detected in Southern Africa. Most countries are jittery and unsure what the impact of this new variant will be. This study, undertaken in 2021, investigated the Knowledge, Attitudes, and Practices (KAP) related to the COVID-19 Pandemic among healthcare workers in the United Arab Emirates (UAE).

Methods: We used an online questionnaire to collect data using the Google Forms link in this crosssectional study. The participants included healthcare workers currently working in UAE healthcare facilities using snowball sampling. The questionnaire contained information on demographic variables and COVID-19 Pandemic-related KAP.

Results: Among the participants, the majority (90.7\%) knew that the absence of fever did not mean there was no chance of transmission from an infected person. Further, $84.1 \%$ agreed that wearing general medical face masks helps prevent one from contracting COVID-19 Pandemic. However, only $36.4 \%$ strongly believed that wearing a well-fitting face mask was effective. In addition, only $15.9 \%$ reported confidently managing patients with symptoms of COVID-19 Pandemic, while $54.2 \%$ indicated they were afraid of contracting the virus from patients. Almost half the participants noted that they avoided patients who had symptoms of the COVID-19 Pandemic.

Conclusion: Overall, the COVID-19 Pandemic-related KAP for healthcare workers in UAE healthcare facilities was very high. However, we found gaps in awareness regarding the spread of the virus. We recommend providing healthcare workers with education programs and counseling services to help increase their confidence in treating patients with the COVID-19 Pandemic.

\section{Introduction}

The ongoing Pandemic of the highly contagious respiratory disease COVID-19 Pandemic is threatening global health ${ }^{[1]}$. The novel coronavirus is structurally related to the virus that causes severe acute respiratory syndrome (SARS). The presence of pneumonia led to the identification of the COVID-19 Pandemic, and close monitoring of the virus suggested a mean incubation period of 5 days ${ }^{\text {[2] }}$. So far, it has appeared in a few variants such as Delta and Omicron and these make several countries jittery and unsure of what to do. The reactions are knee-jerk and involves locking out travel to the countries where they first detected the variant.

COVID-19 Pandemic spreads via the respiratory secretions of infected persons when they cough or sneeze, especially in poorly ventilated or crowded places. COVID-19 Pandemic is a highly infectious disease. However, most infected people recover without special treatment. Notwithstanding, older people 
and those with chronic disease conditions such as diabetes or respiratory infections are more likely to develop severe symptoms and higher mortality ${ }^{[3]}$. The global mortality rate is about $2 \%{ }^{[4]}$.

No medicine is currently available to treat COVID-19 Pandemic even though various clinical trials are taking place to evaluate potential treatments. However, supportive healthcare interventions are available to hospitalized patients. It means that infection prevention and vaccines areas are the only way to control the Pandemic. The best way to prevent and slow virus transmission is to ensure people are well informed about COVID-19 Pandemic, understand how it spreads, are aware of the basic preventive measures, in addition to the global rollout of vaccinations". The simple daily actions that can help prevent the spread of the virus include social distancing, wearing a face mask, washing hands or using alcohol-based sanitizers, and staying home when experiencing any symptoms to avoid spreading the virus to others.

\subsection{Burden of COVID-19 PANDEMIC}

COVID-19 Pandemic has negatively affected many sectors of the economy, including health, business, education, aviation, tourism, and others. The study that explored differences in the socio-economic impact of the COVID-19 Pandemic in the Eastern Democratic Republic of Congo reported that COVID-19 Pandemic had had a significantly more adverse effect on the economy than the Ebola virus disease despite the lower mortality rate of COVID-19 Pandemic ${ }^{[5]}$. This economic impact is attributed to factors such as implementing preventive measures (social distancing, curfews), which mean that people spend less time in social spots, including cafés and restaurants. Staff issues due to the virus have also adversely affected business owners, with staff morale affected by salary cuts and employment termination ${ }^{[6]}$. Analysis of the impact of the Pandemic on small businesses in the United States reported that the economy declined by around 13.8 million from February to April 2020[7].

Preventive measures such as social distancing and lockdowns have also restricted the movement of people within and across countries. Increased demand for transport has resulted in higher fares and costs for transporting goods, which has been catastrophic for emerging economies such as Nigeria [8]. During the second quarter of 2020, the use of transport dropped dramatically around the world. Commercial travel declined by $75 \%$ and shipping by almost $50 \%$ on average from $75 \%$ in mid-April 2020 [9]. Travel restrictions also impacted tourism. It affected developed countries like those in Europe and less developed countries such as the Maldives or Seychelles, which experienced a massive loss of livelihoods [10]. 
The education sector also suffered adverse consequences from the Pandemic, including temporary school closures, which affected about $60 \%$ of students globally ${ }^{[11]}$. All schools in the United Arab Emirates (UAE) were closed temporarily, and new teaching methods such as online learning were introduced ${ }^{[11]}$. The UAE AI Qassimi Foundation indicated that students, staff, and parents experienced high stress during this time ${ }^{[12]}$. Working parents and students with special needs also faced significant difficulties with the new teaching/learning methods, although support was provided through, for example, free internet packages and tutorials ${ }^{[12]}$.

\subsection{Impact of COVID-19 Pandemic on Health Sector}

The Impact of the COVID-19 Pandemic on the healthcare sector has also impacted social relationships through fear of contracting an infection from other people, and people have been particularly anxious about losing family members to COVID-19 Pandemic ${ }^{[13]}$. Limits on physical contact have caused distress for many people, especially those separated from loved ones or unable to leave foreign countries because of flight restrictions.

COVID-19 Pandemic has had an even more significant impact on hospitals and other healthcare facilities in general ${ }^{[14]}$. For example, during the COVID-19 Pandemic, patients with chronic conditions and those requiring less urgent care have avoided visiting hospitals. It has, in turn, has resulted in hospitals sustaining financial losses ${ }^{[15]}$. In response, hospitals have adopted better hygiene practices, including protecting healthcare workers and the effective handling and treatment of COVID-19 Pandemic and nonCOVID-19 Pandemic patients. However, many hospitals have not sustained these practices, which has, in turn, increased the possibility of healthcare workers becoming infected with the COVID-19 Pandemic ${ }^{[16]}$.

A study by Shaukat et al. noted that healthcare workers handling COVID-19 Pandemic cases are at an increased risk of negative impacts on their physical and mental health ${ }^{[17]}$. Their scoping review found that the COVID-19 infection linked multiple factors, including working in high-risk areas and closely contacting patients (e.g., over 12 times per day for more than 15 hours). Furthermore, found common symptoms among healthcare workers include fever (85\%), cough (70\%), fatigue (70\%), and skin damage (97\%). In addition, healthcare workers experienced high levels of depression, anxiety, insomnia, and distress, with nurses and female healthcare workers being highly affected.

A study of healthcare workers in Saudi Arabia showed relatively little knowledge about the causative agent of the COVID-19 Pandemic (45\%). However, their knowledge of COVID-19 Pandemic risk factors 
(close contact with infected people) and the use of antibiotics to treat the COVID-19 Pandemic was higher (97\% and $63 \%$, respectively) ${ }^{[18]}$. The study also demonstrated that most healthcare workers (92\%) were afraid of being carriers of the virus and potential sources of infection to their families. Accordingly, most of them cleaned their hands as often as they could (87\%) and wore masks $(71 \%)$. Given their exposure to patients, healthcare workers are at high risk of contracting the COVID-19 Pandemic. Therefore, it is essential to ensure that all healthcare workers acquire the appropriate knowledge, attitudes, and practices (KAP) to reduce their potential from being infected by their patients.

\subsection{Objectives:}

The primary aim of this study was to identify the KAP of healthcare professionals handling the COVID-19 patients in the UAE. This information is essential as the KAP toward COVID-19 Pandemic adopted by healthcare workers affects their ability to treat and manage patients with confirmed or suspected COVID19.

\section{Methods And Materials}

\subsection{Study Design and Setting}

We used a cross-sectional study design undertaken in 2021. The participants were from Sharjah, Dubai, Abu Dhabi, Ajman, and Umm al Quwain health facilities. The health workers were from different specialties, such as physicians, radiographers, nurses, and pharmacists.

\subsection{Participants and Sample Size}

The target population comprised healthcare workers in the UAE who may have encountered patients with confirmed or suspected COVID-19 Pandemic in 2021. As of 2017, the healthcare worker population in the UAE was $113,000{ }^{[22]}$. We used a software called Creative Research Systems software to estimate the sample size and came up with a sample size of $384^{[21]}$. However, we undertook this study when the government had imposed a lockdown due to COVID-19 Pandemic, and we could only use email and other social media to distribute the survey instrument. Due to these challenges related to the Pandemic, we received responses from 107 respondents.

\subsection{Data collection}

Using an online survey, adapted from the studies of Rabbani and Al Saigul ${ }^{[18]}$, Olum et al. ${ }^{[19]}$, and Ferdous et al. [20], we contextualized the questions to the UAE. We tested it on five people to validate the 
questionnaire. Due to the lockdown restrictions imposed by the government during the Pandemic, the questionnaires were distributed via social media, and the participants completed the questionnaires online using Google Forms.

We used the snowball sampling technique to recruit the participants for this study. It is a non-probability sampling technique in which the identified study participants recruit future participants from among their connections ${ }^{[23]}$. Due to the COVID-19 Pandemic restrictions and related issues, healthcare workers were asked to complete the survey and forward the link to their colleagues in other healthcare facilities.

\subsection{Data analysis}

We used Statistical Package for Social Sciences (SPSS) version 21 to analyze the data ${ }^{[24]}$. Results were presented as descriptive statistics (namely, means, frequencies, and percentages). We also used crosstabulation to display the relationships between the participants' demographic variables and responses to the KAP variables.

\subsection{Ethical considerations}

This study followed the procedures set out in the Declaration of Helsinki and obtained the University of Sharjah's ethical approval from the University Research Ethics Committee (ID: REC-21-02-21-02-S). We sent information about the survey to the participants. We advised them that clicking on the survey link meant that they had consented to participate.

\section{Results}

\subsection{Demographic characteristics}

Approximately $92 \%$ of the participants worked in public healthcare facilities. The mean age of the participants was $40.5 \pm 11$ years, and $67.3 \%$ were female. Most of the participants (87\%) worked in the emirate of Dubai. The participants were classified by occupation as follows: specialist physicians $(16.8 \%)$, radiographers $(43 \%)$, nurses $(23.4 \%)$, pharmacists $(8.4 \%)$, and other $(8.4 \%)$. The majority of the participants had a bachelor's degree (66.4\%) as their highest level of education (Table 1).

Insert Table 1 about here

\subsection{Knowledge}


The participants' responses regarding their knowledge of the COVID-19 Pandemic are presented in Table 2. Most of the participants (94\%) were aware that there was no cure for the COVID-19 Pandemic, but that early diagnosis and supportive interventions would help patients recover faster. The majority of the participants (78.5\%) disagreed with the statement that eating contaminated food could cause Covid-19, but $21.5 \%$ agreed. In addition, $91 \%$ agreed that the absence of a fever does not mean that individuals with the COVID-19 Pandemic could not infect others. In terms of virus spread, $94.4 \%$ of the participants knew that the COVID-19 Pandemic spreads through the respiratory droplets of infected individuals, and $84.1 \%$ agreed with the statement that wearing a general medical mask helps prevent one from contracting COVID-19 Pandemic. Most of the participants (93\%) agreed that children and young adults need to take preventive measures against the COVID-19 Pandemic, and 90\% indicated that individuals should avoid crowded places to reduce the possibility of COVID-19 Pandemic infection. Ninety-six percent knew that the isolation of infected patients for 14 days is an effective way to reduce the spread of the virus.

Insert Table 2 bout here

\subsection{Attitudes}

Table 3 presents the participants' responses regarding their attitudes toward COVID-19 Pandemic. Approximately $25 \%$ agreed that the younger population groups do not contract the COVID-19 Pandemic. Most of the participants (90\%) agreed or strongly agreed that wearing a well-fitting mask is effective in helping prevent individuals from contracting the virus. $88 \%$ agreed or strongly agreed that washing hands with soap could help prevent one from being infected with the virus (Table 3 ). Only $43.9 \%$ of the participants agreed that they confidently participated in managing patients who had signs and symptoms of COVID-19 P Pandemic, with 50.5\% afraid of carrying the virus from their workplace to home and $54.2 \%$ fearful of contracting the virus from patients. Most participants agreed (49.5\%) or strongly agreed $(55.1 \%)$ that their workplaces were clean from the COVID-19 Pandemic. Interestingly, 55.1\% agreed, and $29.9 \%$ strongly agreed that the UAE was in a position to contain the virus.

Insert Table 3 bout here

\subsection{Practices}

The participants' responses concerning COVID-19 Pandemic practices are presented in Table 4. Almost all the participants (97.2\%) always wore masks during patient contact, $85 \%$ always refrained from shaking hands, and $91.6 \%$ always washed their hands before and after handling each patient. Surprisingly, $49.5 \%$ 
of the participants indicated that they always avoided patients with signs and symptoms of COVID-19 Pandemic. Most of the participants (86.0\%) indicated that they always educated their patients about COVID-19 Pandemic preventive measures, and $95.3 \%$ always obeyed all government rules related to COVID-19 Pandemic. $94.4 \%$ of the participants indicated that they always maintained social distancing.

Insert Table 4 bout here

Furthermore, $26.2 \%$ of the respondents occasionally tried to avoid patients with COVID-19 Pandemic symptoms, while $24.3 \%$ never tried to prevent such patients. Table 5 shows the relationships between COVID-19 Pandemic-related KAP and the participants' age groups. We found that only the participants in the 31-40-year age group believed that the statement that a person without a fever could not transmit COVID-19 Pandemic to others was genuine. In addition, all the respondents aged 51-60 years agreed with the statement that using a general medical mask helped prevent COVID-19 Pandemic infection, with agreement relatively high across all the other age groups.

Insert Table 5 bout here

\section{Discussion}

Our study showed that the participating healthcare workers in the UAE had sufficient knowledge about COVID-19 Pandemic. For example, most were aware that although COVID-19 Pandemic has no cure, early diagnosis and supportive care can help most patients recover ${ }^{[20]}$. Furthermore, most participants understood that the absence of fever did not mean the lack of COVID-19 Pandemic. A study by Olum et al. found a high level of COVID-19 Pandemic knowledge among healthcare workers ${ }^{[19]}$. In our study, only a few participants (8.4\%) believed that children and young adults could avoid infection with the COVID-19 Pandemic, consistent with the findings of Ferdous et al., who reported that $4 \%$ of the respondents in their study held this belief [20]. Encouragingly, as for Olum et al. ${ }^{[19]}$, most of the participants in our research agreed/strongly agreed that wearing a well-fitting mask is effective in helping prevent COVID-19 Pandemic infection. Frequent reminders via official international and governmental websites may explain the relatively high rate of knowledge about the protective effect of masks. To enforce the use of shows, the UAE has strict rules and fines for individuals who are non-compliant with this requirement ${ }^{[19]}$.

Our results suggested some debate about whether contaminated food is a source of infection. While $80 \%$ of the participants believed that avoiding crowded places helps protect people from COVID-19 Pandemic infection, 9.3\% did not share this view. Strong adherence to social distancing and wearing face masks are 
considered effective in combatting COVID-19 Pandemic spread. Healthcare workers can play a role in guiding the public about practicing precautionary measures to help reduce the spread of the disease ${ }^{[19]}$.

In our study, most healthcare workers reported fear and stress about caring for the COVID-19 pandemic patients. Healthcare workers in the older age groups were particularly conscious of the risk of COVID-19 Pandemic transmission, which may be because older people are susceptible to severe COVID-19 Pandemic outcomes as many tend to have preexisting conditions. We found that many participants were not confident in managing patients who had signs and symptoms of the COVID-19 Pandemic, and 54\% indicated that they always wore masks during patient contact. Our results further demonstrated that most of the participants refrained from shaking hands, and the majority always washed their hands before and after handling a patient. Strict rules and practices concerning hand hygiene were implemented in hospitals throughout the UAE as the Pandemic worsened in 2020.

The majority of the study participants maintained social distancing. Similarly, Ferdous et al. found that $90.8 \%$ of the participants in their study supported social distancing ${ }^{[20]}$, which could be because of government rules worldwide and constant reminders about maintaining distance for safety. Overall, the healthcare workers in our study adhered to the government's rules regarding preventive measures (Table 4). Similarly, $92 \%$ of the participants in Ferdous et al.'s study were afraid of carrying the virus home. At the same time, $76 \%$ agreed that their institutions were well-prepared for the Pandemic ${ }^{[20]}$. In our study, most of the healthcare workers educated their patients about COVID-19 Pandemic preventive measures. WHO and related institutions have guided countries on their responses to COVID-19 Pandemic during the Pandemic, and many countries have relied on these announcements and guidelines to encourage people to adhere to public health measures. The UAE established the National Crisis and Emergency Management Authority in 2010. This authority established field hospitals and devised comprehensive plans to respond to the COVID-19 Pandemic, including free PCR testing and, later, free vaccinations for the population. Providing ongoing education and support for healthcare professionals to improve their COVID-19 Pandemic-related KAP will help strengthen the UAE's response to the current Pandemic and similar public health issues that may arise in the future.

\section{Conclusion}

COVID-19 Pandemic brought about unprecedented circumstances globally. The UAE government is actively expanding and strengthening its public health efforts to curb the spread of the virus through restrictions and precautionary guidelines. These guidelines primarily prevent the spread of the COVID-19 Pandemic and protect healthcare workers from infection. This study shows a strong need for professional education among healthcare workers to continuously and rigorously update their KAP to prepare them for unforeseeable future events and pandemics. The healthcare workers in this study 
believed that mask and social distancing protocols could help prevent them from becoming infected with the COVID-19 Pandemic. However, it is not easy at this point to attribute the proportion of this willingness to use face masks and maintain social distancing to the knowledge or attitudes of healthcare workers beyond government regulations. Indeed, some healthcare workers do not believe in using masks and social distancing. Unfortunately, this can undermine the government's efforts to curb the COVID-19 Pandemic among healthcare workers and society. Interventions are needed to improve awareness among healthcare workers via orientation and continuing education programs.

It was necessary to gauge the levels of healthcare workers' COVID-19 Pandemic knowledge and their attitudes toward COVID-19 Pandemic, given their beliefs and cultural orientations and the fact that most healthcare workers in the UAE are foreigners. The practice related to the COVID-19 Pandemic among healthcare workers in the UAE requires a better understanding of the factors influencing the spread of the COVID-19 Pandemic. More research on the KAP among these healthcare workers is essential to help the government understand how to improve healthcare and health outcomes about the COVID-19 Pandemic and other illnesses.

Institutions should enforce precautions and protective measures against COVID-19 for healthcare professionals so that they, their families, and the wider community are protected. Furthermore, we recommend that healthcare facilities include counseling services for workers who lack confidence when treating patients with the COVID-19 Pandemic. In addition, having incentives in place for healthcare workers to participate in continuous professional development is essential. Healthcare worker educational institutions should also embed public health measures, such as attitudes and professional practices, concerning Pandemic in their academic programs and curricula in the UAE. Finally, preparedness and continuity during crises and emergencies should be introduced into the healthcare system to prepare and change the attitudes of healthcare workers.

A limitation of our study is that the findings cannot be generalized due to the small sample size, which is not representative. Most of the participants were from Dubai because social distancing and other restrictions at the time of the study hindered data collection, potentially excluding survey participants who did not have internet access.

\section{Declarations}

\section{Acknowledgements}

We would like to thank Dr. Heba Hijazi for her comments on the final script. 


\section{Ethical approval and participant consent}

Ethical approval for this study was obtained from the University Research Ethics Committee (ID: REC-2102-21-02-S). Information about the study was posted on the front page of the Google Forms questionnaire. This included a statement asking the participants to confirm that they were healthcare workers currently working in the UAE. They were then advised that when clicking on the survey link, they were consenting to participate in this study.

\section{Consent for publication}

Not applicable.

\section{Availability of data and materials}

The datasets generated during the present study are not publicly available because of ethical restrictions but are available from the corresponding author on reasonable request.

\section{Competing interests}

The authors declare that they have no competing interests.

\section{Funding}

None to declare.

\section{References}

1. Fauci AS, Lane HC, \& Redfield RR. COVID-19 Pandemic - navigating the uncharted. N Eng/ J Med, (2020), 382(13), 1268-1269. doi:10.1056/NEJMe2002387 [Accessed January 2021]

2. Velavan, T. P., \& Meyer, C. G.). The COVID-19 Pandemic. Tropical Medicine \& International Health: TM \& IH, (2020) 25(3), 278-280. doi:10.1111/tmi.13383 [Accessed January 2021]

3. Radwan, N. M., Mahmoud, N. E., Alfaif, A. H., \& Alabdulkareem, K. I. (2020). Comorbidities and severity of coronavirus disease 2019 patients. International Journal of Infectious Diseases, 99, 47-56. Retrieved from https://www.sciencedirect.com/science/article/pii/S1201971220305725 [Accessed January 2021]

4. WHO Coronavirus Disease (COVID-19 Pandemic) Dashboard. (2021). [Accessed February 2021] Retrieved from https://covid19.who.int/

5. Stoop, N., Desbureaux, S., Kaota, A., Lunanga, E., \& Verpoorten, M.. COVID-19 Pandemic vs. ebola: Impact on households and small businesses in north kivu, democratic republic of congo. World Development, (2021), 140 doi: 10.1016/j.worlddev.2020.105352 [Accessed Jan 2021] 
6. Al-Fadly, A. Impact of COVID-19 Pandemic on smes and employment. Entrepreneurship and Sustainability Issues, (2020), 8(2), 629-648. doi:10.9770/jesi.2020.8.2(38) [Accessed January 2021]

7. Fairlie, R. (2020). The impact of COVID-19 on small business owners: Evidence from the first threemonths after widespread social-distancing restrictions. Journal of Economics \& Management Strategy, 29(4), 727-740. doi: http://dx.doi.org/10.1111/jems.12400 [Accessed January 2021]

8. Mogaji, E. (2020). Impact of COVID-Pandemic on transportation in Lagos, Nigeria. Transportation Research Interdisciplinary Perspectives, 6, 100154. Doi: 10.1016/j.trip.2020.100154 [Accessed January 2021].

9. Abu-Rayash, A., \& Dincer, I. (2020). Analysis of mobility trends during the COVID-19 Pandemic coronavirus Pandemic : Exploring the impacts on global aviation and travel in selected cities. Energy Research \& Social Science, 68, 101693. doi: https://doi.org/10.1016/j.erss.2020.101693 [Accessed January 2021]

10. Jones, P., \& Comfort, D. (2020). The COVID-19 Pandemic crisis, tourism and sustainable development. Athens Journal of Tourism, 7(2), 75-86. Retrieved from https://www.athensjournals.gr/tourism/2020-7-2-1-Jones.pdf [Accessed January 2021]

11. Aldarayesh, A. (2020). The Impact of COVID-19 Pandemic on Modes of Teaching Science in UAE Schools. doi: 10.7176/JEP/11-20-13 [Accessed January 2021]

12. Ridge, N., \& Erfurth, M. (2020). The Impact of COVID-19 Pandemic on Education in the UAE. Al Qasimi Foundation. doi:10.18502/aqf.0143 [Accessed January 2021]

13. Lebow, J. (2020). Family in the Age of COVID-19. Family Process, 59(2), 309-312. doi:10.1111/famp.12543 [Accessed January 2021]

14. Birkmeyer, J., Barnato, A., Birkmeyer, N., Bessler, R., \& Skinner, J. (2020). The Impact of the COVID-19 Pandemic On Hospital Admissions in The United States. Health Affairs, 39(11), 2010-2017. doi:10.1377/hlthaff.2020.00980 [Accessed February 2021]

15. The Effect of COVID-19 Pandemic on Hospital Financial Health | AHA. (2020). American Hospital Association. https://www.aha.org/guidesreports/2020-07-20-effect-COVID-19 Pandemic -hospitalfinancial-health. [Accessed February 2021]

16. Moore, L., Robbins, G., Quinn, J., \& Arbogast, J. (2021). The impact of COVID-19 Pandemic on hand hygiene performance in hospitals. American Journal of Infection Control, 49(1), 30-33. Doi: 10.1016/j.ajic.2020.08.021 [Accessed February 2021]

17. Shaukat, N., Ali, D., \& Razzak, J. (2020). Physical and mental health impacts of COVID-19 Pandemic on healthcare workers: a scoping review. International Journal of Emergency Medicine, 13(1). Doi:10.1186/s12245-020-00299-5 [Accessed January 2021]

18. Rabbani, U., \& Al Saigul, A. (2020). Knowledge, Attitude and Practices of Health Care Workers about Corona Virus Disease 2019 in Saudi Arabia. Journal of Epidemiology and Global Health. doi:10.2991/jegh.k.200819.002. [Accessed January 2021]

19. Olum, R., Chekwech, G., Wekha, G., Nassozi, D., \& Bongomin, F. (2020). Coronavirus Disease-2019: Knowledge, Attitude, and Practices of Health Care Workers at Makerere University Teaching 
Hospitals, Uganda. Frontiers in Public Health, 8. doi:10.3389/fpubh.2020.00181 [Accessed February 2021]

20. Ferdous, M., Islam, M., Sikder, M., Mosaddek, A., Zegarra-Valdivia, J., \& Gozal, D. (2020). Knowledge, attitude, and practice regarding COVID-19 Pandemic outbreak in Bangladesh: An online-based crosssectional study. PLOS ONE, 15(10), e0239254. doi:10.1371/journal.pone. 0239254 [Accessed February 2021]

21. Sample Size Calculator - Confidence Level, Confidence Interval, Sample Size, Population Size, Relevant Population - Creative Research Systems.

(n.d.). https://www.surveysystem.com/sscalc.htm [Accessed December 2020]

22. UAE: healthcare workers total numbers | Statista. (2020). Statista.

https://www.statista.com/statistics/1120454/uae-number-of-healthcare-workers/ [Accessed December 2020]

23. Taherdoost, H. (2016). Sampling Methods in Research Methodology; How to Choose a Sampling Technique for Research (pp. 18-22). Switzerland. [Accessed January 2021].

24. IBM-International Business Machines, Statistical Package for the Social Sciences (SPSS) Version 21. 2020. https://www.ibm.com/support/pages/spss-statistics-210-available-download [Accessed January 2021]

\section{Tables}

Table 1: Demographic characteristics of the participants 


\begin{tabular}{|c|c|c|}
\hline Characteristic & Variable & n (\%) \\
\hline \multirow[t]{2}{*}{ Workplace } & Private & $\begin{array}{l}9 \\
(8.4)\end{array}$ \\
\hline & Public & $\begin{array}{l}98 \\
(91.6)\end{array}$ \\
\hline \multirow[t]{3}{*}{ Emirate } & Dubai & $\begin{array}{l}93 \\
(86.9)\end{array}$ \\
\hline & Sharjah & $\begin{array}{l}9 \\
(8.4)\end{array}$ \\
\hline & Others & $\begin{array}{l}5 \\
(4.6)\end{array}$ \\
\hline \multirow[t]{2}{*}{ Gender } & Male & $\begin{array}{l}35 \\
(32.7)\end{array}$ \\
\hline & Female & $\begin{array}{l}72 \\
(67.3)\end{array}$ \\
\hline \multirow[t]{4}{*}{ Age, years } & $21-30$ & $\begin{array}{l}21 \\
(19.6)\end{array}$ \\
\hline & $31-40$ & $\begin{array}{l}37 \\
(34.6)\end{array}$ \\
\hline & $41-50$ & $\begin{array}{l}24 \\
(22.4)\end{array}$ \\
\hline & $51-60$ & $\begin{array}{l}25 \\
(23.4)\end{array}$ \\
\hline \multirow[t]{5}{*}{ Qualification } & Specialist physician & $\begin{array}{l}18 \\
(16.8)\end{array}$ \\
\hline & Radiographer & $\begin{array}{l}46 \\
(43.0)\end{array}$ \\
\hline & Nurse & $\begin{array}{l}25 \\
(23.4)\end{array}$ \\
\hline & Pharmacist & $\begin{array}{l}9 \\
(8.4)\end{array}$ \\
\hline & & \\
\hline
\end{tabular}




\begin{tabular}{|c|c|c|}
\hline & Other & $\begin{array}{l}9 \\
(8.4)\end{array}$ \\
\hline \multirow[t]{4}{*}{ Education } & Diploma & $\begin{array}{l}139 \\
(12.1)\end{array}$ \\
\hline & Bachelor's degree & $\begin{array}{l}71 \\
(66.4)\end{array}$ \\
\hline & Master's degree & $\begin{array}{l}16 \\
(15.0)\end{array}$ \\
\hline & Doctor of Philosophy & $\begin{array}{l}7 \\
(6.5)\end{array}$ \\
\hline \multirow[t]{4}{*}{ Nationality } & Philippines & $\begin{array}{l}30 \\
(28.0)\end{array}$ \\
\hline & India & $\begin{array}{l}30 \\
(28.0)\end{array}$ \\
\hline & UAE & $\begin{array}{l}14 \\
(13.1)\end{array}$ \\
\hline & Other & $\begin{array}{l}33 \\
(30.8)\end{array}$ \\
\hline \multirow[t]{5}{*}{$\begin{array}{l}\text { Source of information on COVID-19 } \\
\text { Pandemic (more than one source may be } \\
\text { identified) }\end{array}$} & $\begin{array}{l}\text { International health organizations } \\
\text { sites such as the WHO and CDC }\end{array}$ & $\begin{array}{l}84 \\
(78.5)\end{array}$ \\
\hline & $\begin{array}{l}\text { Government sites (such as } \\
\text { Ministry of Health) }\end{array}$ & $\begin{array}{l}91 \\
(85)\end{array}$ \\
\hline & $\begin{array}{l}\text { News media (such as Televisions } \\
\text { and radio) }\end{array}$ & $\begin{array}{l}57 \\
(53.3)\end{array}$ \\
\hline & $\begin{array}{l}\text { Social media (such as WhatsApp } \\
\text { and Facebook) }\end{array}$ & $\begin{array}{l}51 \\
(47.7)\end{array}$ \\
\hline & Journals & 1. 29.9) \\
\hline
\end{tabular}

Table 2: Knowledge about COVID-19 Pandemic among healthcare workers in the United Arab Emirates 


\begin{tabular}{|c|c|}
\hline Variable & n (\%) \\
\hline \multicolumn{2}{|c|}{ Major clinical symptoms of COVID-19 PANDEMIC } \\
\hline Fever & $107(100)$ \\
\hline Headache & $91(85)$ \\
\hline Myalgia (muscle pain) & $80(74.8)$ \\
\hline Smell disturbance & $87(81.3)$ \\
\hline Sore throat & $98(91.6)$ \\
\hline Diarrhea & $71(66.4)$ \\
\hline Runny nose & $61(57)$ \\
\hline Sneezing & $56(52.3)$ \\
\hline Cough & $104(97.2)$ \\
\hline Confusion & $23(21.5)$ \\
\hline \multicolumn{2}{|c|}{ There is currently no cure for COVID-19 Pandemic. } \\
\hline True & $100(93.5)$ \\
\hline False & $4(3.7)$ \\
\hline I don't know & $3(2.8)$ \\
\hline \multicolumn{2}{|c|}{$\begin{array}{l}\text { Not all COVID-19 Pandemic patients will develop severe illness, only those with chronic } \\
\text { illnesses. }\end{array}$} \\
\hline True & $84(78.5)$ \\
\hline False & $19(17.8)$ \\
\hline I don't know & $4(3.7)$ \\
\hline \multicolumn{2}{|c|}{ Contaminated food and seafood could result in COVID-19 infection. } \\
\hline True & $23(21.5)$ \\
\hline False & $68(63.6)$ \\
\hline I don't know & $16(15.0)$ \\
\hline \multicolumn{2}{|c|}{ COVID-19 Pandemic patients cannot transmit the virus when a fever is not present. } \\
\hline True & $5(4.7)$ \\
\hline False & $97(90.7)$ \\
\hline I don't know & $5(4.7)$ \\
\hline \multicolumn{2}{|c|}{ The COVID-19 virus spreads via the respiratory droplets of infected individuals. } \\
\hline True & $101(94.4)$ \\
\hline False & $3(2.8)$ \\
\hline I don't know & $3(2.8)$ \\
\hline \multicolumn{2}{|c|}{ Wearing a mask can help prevent one from acquiring COVID-19 virus. } \\
\hline True & $90(84.1)$ \\
\hline False & $14(13.1)$ \\
\hline I don't know & $3(2.8)$ \\
\hline \multicolumn{2}{|c|}{ Children and young adults should avoid becoming infected with COVID-19. } \\
\hline True & $9(8.4)$ \\
\hline
\end{tabular}




\begin{tabular}{|l|c|} 
False & $94(87.9)$ \\
\hline I don't know & $4(3.7)$ \\
\hline $\begin{array}{l}\text { Individuals should avoid going to crowded places to prevent COVID-19 transmission and } \\
\text { infection. }\end{array}$ \\
\hline True & $96(89.7)$ \\
\hline False & $10(9.3)$ \\
\hline I don't know & $1(0.9)$ \\
\hline People who are infected with COVID-19 Pandemic should be isolated and treated. \\
\hline True & $103(96.3)$ \\
\hline False & $3(2.8)$ \\
\hline I don't know & $1(0.9)$ \\
\hline Contact with someone with COVID-19 Pandemic requires 14 days of observation. \\
\hline True & $102(95.3)$ \\
\hline False & $3(2.8)$ \\
\hline I don't know & $1 .(1.9)$ \\
\hline
\end{tabular}

Table 3: Attitudes toward COVID-19 Pandemic among healthcare workers in the United Arab Emirates 


\begin{tabular}{|c|c|}
\hline Variables & n (\%) \\
\hline \multicolumn{2}{|c|}{ Young population groups are protected against COVID-19 Pandemic } \\
\hline Strongly disagree & $32(29.9)$ \\
\hline Disagree & $29(27.1)$ \\
\hline Not sure & $19(17.8)$ \\
\hline Agree & $17(15.9)$ \\
\hline Strongly agree & $10(9.3)$ \\
\hline \multicolumn{2}{|c|}{ Wearing a well-fitting face mask is effective in helping prevent COVID-19 Pandemic. } \\
\hline Strongly disagree & $6(5.6)$ \\
\hline Disagree & $2(1.9)$ \\
\hline Not sure & $3(2.8)$ \\
\hline Agree & $57(53.3)$ \\
\hline Strongly agree & $39(36.4)$ \\
\hline \multicolumn{2}{|c|}{$\begin{array}{l}\text { Washing with soap can help prevent you from becoming infected with COVID- } \\
19 \text { Pandemic. }\end{array}$} \\
\hline Strongly disagree. & $5(4.7)$ \\
\hline Disagree & $4(3.7)$ \\
\hline Not sure & $4(3.7)$ \\
\hline Agree & $60(56.1)$ \\
\hline Strongly agree & $34(31.8)$ \\
\hline \multicolumn{2}{|c|}{$\begin{array}{l}\text { When a patient has signs and symptoms of COVID-19 Pandemic, I can confidently } \\
\text { participate in the management of the patient. }\end{array}$} \\
\hline Strongly disagree & $10(9.3)$ \\
\hline Disagree & $15(14.0)$ \\
\hline Not sure & $18(16.8)$ \\
\hline Agree & $47(43.9)$ \\
\hline Strongly agree & $17(15.9)$ \\
\hline \multicolumn{2}{|c|}{ I am afraid of carrying COVID-19 virus from my workplace to my home. } \\
\hline Strongly disagree & $3(2.8)$ \\
\hline Disagree & $7(6.5)$ \\
\hline Not sure & $11(10.3)$ \\
\hline Agree & $54(50.5)$ \\
\hline Strongly agree & $32(29.9)$ \\
\hline \multicolumn{2}{|c|}{ I am afraid of contracting COVID-19 virus from patients. } \\
\hline Strongly disagree & $4(3.7)$ \\
\hline Disagree & $18(16.8)$ \\
\hline Not sure & $8(7.5)$ \\
\hline
\end{tabular}




\begin{tabular}{|l|l|}
\hline Agree & $58(54.2)$ \\
\hline Strongly agree & $19(17.8)$ \\
\hline My workplace is adequately equipped to curb the spread of COVID-19 Virus. \\
\hline Strongly disagree & $2(1.9)$ \\
\hline Disagree & $9(8.4)$ \\
\hline Not sure & $16(15.0)$ \\
\hline Agree & $53(49.5)$ \\
\hline Strongly agree & $27(25.2)$ \\
\hline My workplace is adequately equipped to protect its employees from COVID-19 virus . \\
\hline Strongly disagree & $3(2.8)$ \\
\hline Disagree & $11(10.3)$ \\
\hline Not sure & $8(7.5)$ \\
\hline Agree & $59(55.1)$ \\
\hline Strongly agree & $26(24.3)$ \\
\hline The UAE is in an appropriate position to contain COVID-19 Pandemic. \\
\hline Strongly disagree & $2(1.9)$ \\
\hline Disagree & $1(0.9)$ \\
\hline Not sure & $13(12.1)$ \\
\hline Agree & $59(55.1)$ \\
\hline Strongly agree & $32(29.9)$ \\
\hline
\end{tabular}

Table 4: COVID-19 Pandemic practices among healthcare workers in the UAE 


\begin{tabular}{|l|c|}
\hline Practices & N (\%) \\
\hline I wear a mask when in contact with patients. & $104(97.2)$ \\
\hline Always & $1(0.9)$ \\
\hline Occasionally & $2(1.9)$ \\
\hline Never & \\
\hline I refrain from shaking hands with people. & $91(85.0)$ \\
\hline Always & $3(2.8)$ \\
\hline Occasionally & $13(12.1)$ \\
\hline Never & \\
\hline I wash my hands before and after handling each patient. & $98(91.6)$ \\
\hline Always & $8(7.5)$ \\
\hline Occasionally & \\
\hline I avoid patients with signs and symptoms suggestive of COVID-19 Pandemic & $53(49.5)$ \\
\hline Always & $28(26.2)$ \\
\hline Occasionally & $26(24.3)$ \\
\hline Never & \\
\hline I educate my patients about COVID-19 Pandemic preventive measures. & $92(86.0)$ \\
\hline Always & $13(12.1)$ \\
\hline Occasionally & $2(1.9)$ \\
\hline Never & \\
\hline I obey all the government's rules related to COVID-19 Pandemic. & $102(95.3)$ \\
\hline Always & $5(4.7)$ \\
\hline Occasionally & $0(0.0)$ \\
\hline Never & \\
\hline I always maintain social distancing. & $101(94.4)$ \\
\hline Always & $6(5.6)$ \\
\hline Never & \\
\hline
\end{tabular}

\section{Table 5: Relationships between COVID-19 Pandemic knowledge, attitudes, and practices and age among healthcare workers in the UAE}




\begin{tabular}{|c|c|c|c|c|c|c|}
\hline \multicolumn{2}{|l|}{ Variables } & \multicolumn{4}{|c|}{ Age, years } & \multirow[t]{2}{*}{ Total } \\
\hline & & $\begin{array}{c}21- \\
30\end{array}$ & $\begin{array}{c}31- \\
40\end{array}$ & $\begin{array}{c}41- \\
50\end{array}$ & $\begin{array}{c}51- \\
60\end{array}$ & \\
\hline \multirow{3}{*}{$\begin{array}{l}\text { People with COVID-19 cannot transmit the } \\
\text { virus to others when a fever is not present. }\end{array}$} & True & 0 & 5 & 0 & 0 & 5 \\
\hline & False & 21 & 29 & 22 & 25 & 97 \\
\hline & $\begin{array}{l}\text { I don't } \\
\text { know }\end{array}$ & 0 & 3 & 2 & 0 & 5 \\
\hline \multicolumn{2}{|l|}{ Total } & 21 & 37 & 24 & 25 & 107 \\
\hline \multirow{5}{*}{$\begin{array}{l}\text { When a patient has signs and symptoms of } \\
\text { COVID-19 Pandemic, I can confidently } \\
\text { participate in their management. }\end{array}$} & $\begin{array}{l}\text { Strongly } \\
\text { Disagree }\end{array}$ & 2 & 5 & 1 & 2 & 10 \\
\hline & Disagree & 2 & 4 & 6 & 3 & 15 \\
\hline & Not Sure & 3 & 7 & 6 & 2 & 18 \\
\hline & Agree & 9 & 15 & 10 & 13 & 47 \\
\hline & $\begin{array}{l}\text { Strongly } \\
\text { Agree }\end{array}$ & 5 & 6 & 1 & 5 & 17 \\
\hline \multicolumn{2}{|l|}{ Total } & 21 & 37 & 24 & 25 & 107 \\
\hline \multirow{3}{*}{$\begin{array}{l}\text { In recent days, I have avoided patients with } \\
\text { Covid-19 signs and symptoms. }\end{array}$} & Always & 10 & 22 & 11 & 10 & 53 \\
\hline & Occasional & 9 & 10 & 5 & 4 & 28 \\
\hline & Never & 2 & 5 & 8 & 11 & 26 \\
\hline \multicolumn{2}{|l|}{ Total } & 21 & 37 & 24 & 25 & 107 \\
\hline
\end{tabular}

